\title{
EXPERIMENTAL INVESTIGATION AND STASTICAL ANALYSIS OF THE FRICTION WELDING PARAMETERS FOR THE COPPER ALLOY - CU Zn28 USING TAGUCHI METHOD
}

\author{
P. Shiva Shankar ${ }^{1}$, L. Suresh Kumar ${ }^{2}$, N. Ravinder Reddy ${ }^{3}$ \\ ${ }^{I}$ Department of mechanical engineering, Ramanandathirta Engineering College, Nalgonda, AP, INDIA. \\ ${ }^{2}$ Department of mechanical engineering, CBIT, Hyderabad. \\ ${ }^{3}$ Department of mechanical engineering, Bhoj Reddy Engineering College, Hyderabad.
}

\begin{abstract}
Friction welding $(F W)$ is a process of solid state joining which is extensively used in present scenario due to most economical, high productive, ease of manufacture and environment friendliness. Friction welding can be used to join different types of Ferrous, Non Ferrous metals and its combinations that cannot be welded by traditional fusion welding process. It is widely used in aerospace and automotive industrial applications. This process employs a machine which converts mechanical energy into heat at the joint to weld using relative movement between work pieces without external heat energy. The process parameters such as Rotational speed, Friction pressure, Friction time, Forge Pressure play major role in determining the high tensile strength of the weld for alloyed material i.e. $\mathrm{Cu} \mathrm{Zn} 28 \mathrm{Pb2}$.Taguchi Method is applied for optimizing the welding parameters to attain maximum tensile strength of the joint and microstructure of the welded joint, base material and heat affected zone is studied with good structure without any defects.
\end{abstract}

Keywords: Friction Welding, Similar, Taguchi Method, Regression ANOVA, Micro structure

\section{INTRODUCTION}

FRICTION WELDING method has been used extensively in the manufacturing methods because of the advantages such as high material saving, low production time, no filler material and good welded joints produced. There are many different methods of friction welding processes; some of them are Rotary, Linear Angular or Orbital types of relative movement between the joining surfaces of parts.

In rotary friction welding process, the work pieces are brought together, one of the work piece is kept stationary and another is being revolved against each other so that frictional heat is generated between the two work pieces. When the joint area is sufficiently plasticized then the rotation of the part is stopped abruptly and the pressure on the stationary work piece is increased so that the joining takes place. This process is termed as Rotational Friction Welding (RFW).

MIMUM [1] investigated the hardness variations and the microstructure at the interfaces of steel welded joints. PAVENTHAN [2] investigated on the optimization of friction welding parameters to get good tensile strength of dissimilar metals. ANANTHAPADMANABAN [3] reported the experimental studies on the effect of friction welding parameters on properties of steel. DOBROVIDOV [4] investigated the selection of optimum conditions for the friction welding of high speed steel to carbon steel. SARALA
UPADHYA [5] studied the mechanical behavior and microstructure of the rotary friction welding of titanium alloy.

From the literature review it is understood most of the experimentation done on the ferrous metals and very few on the non- ferrous metals. All the above investigations were carried out on trial and other basis to attain optimum welding strength. Hence in this investigation an attempt was made on similar non- ferrous metal which has low co-efficient of friction (0.15) to optimize the friction welding parameters for attaining good tensile strength in $\mathrm{Cu} \mathrm{Zn} 28$ using TAGUCHI METHOD.

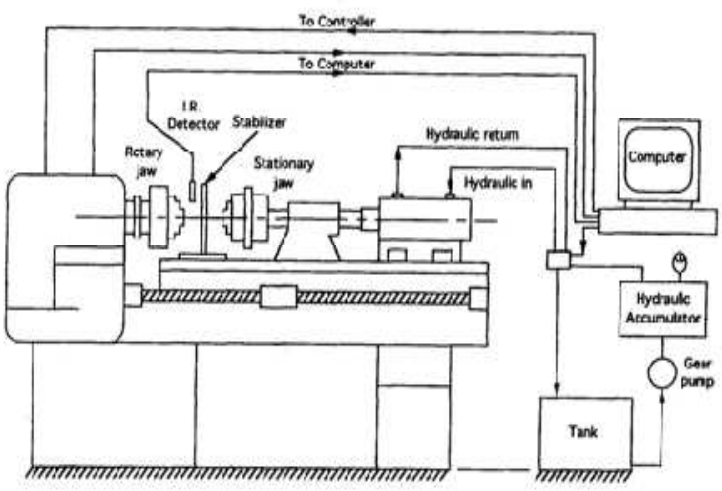

Fig1: Setup of friction welding machine 


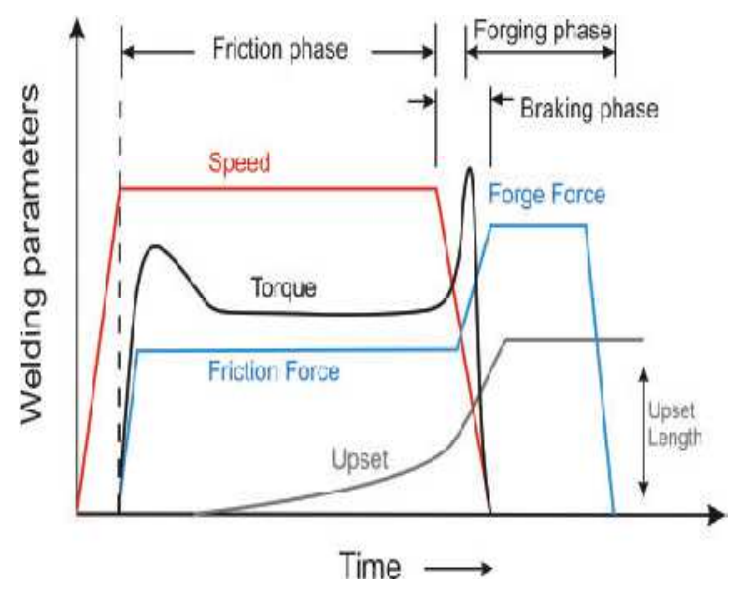

Fig shows welding parameters to time

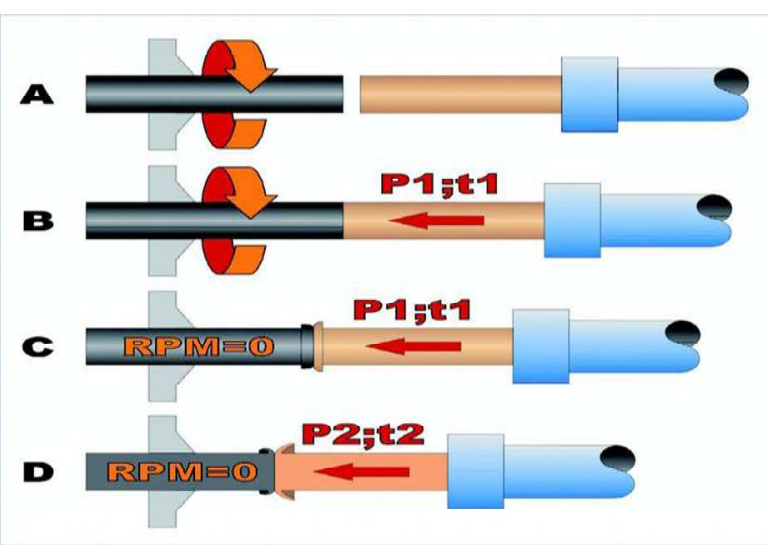

Fig: 2 Sequence of operation in the friction welding process

\section{EXPERIMENTAL DETAILS}

A continuous drive friction welding machine type FWT - 12 with a maximum load of $120 \mathrm{KN}$ was used for welding. The material used in the present investigation was Copper Alloy: $\mathrm{Cu} \mathrm{Zn} 28$ with chemical composition of the base material as shown in the table 1 . The specimens are of size $19 \mathrm{~mm}$ diameters and length of $90-100 \mathrm{~mm}$ after facing operation were used as the parent material in the study. From the literature the predominant factor which has great influence on the tensile strength of the friction weld (FW) joints were identified. Trial experiments were conducted to determine the working range of the parameters. The feasible limits of the parameters were chosen in such a way that it is not effecting external defects. The important parameters influencing the tensile strength are speed of spindle C1 (RPM) of 1400 - 1600rpm, friction time C2 $4-5 \mathrm{sec}$, friction pressure C3 10- 20 bar and forge pressure c4 20-30 bar and were used to produced the welded joint of the given material. The other parameters of the process are: forging time: $3 \mathrm{sec}$, Braking time: $0.1 \mathrm{sec}$, Upset time: $0.3 \mathrm{sec}$ and Feed: $75 \%$ is kept constant.

\section{TABLE 1: CHEMICAL COMPOSITION OF COPPER ALLOY}

\begin{tabular}{|c|l|}
\hline Element & Composition(\%) \\
\hline $\mathrm{Cu}$ & 70 \\
\hline $\mathrm{Zn}$ & 28 \\
\hline $\mathrm{Pb}$ & 2 \\
\hline
\end{tabular}

Different parameters and their levels for the present work were given in table2

TABLE 2: Friction welding factors for 3 levels

\begin{tabular}{|l|l|l|l|}
\hline $\begin{array}{l}\text { Levels } \\
\text { Factors }\end{array}$ & High & Medium & Low \\
\hline C1 & 1600 & 1500 & 1400 \\
\hline C2 & 6 & 5 & 4 \\
\hline C3 & 20 & 15 & 10 \\
\hline C4 & 30 & 25 & 20 \\
\hline
\end{tabular}

Taking all the parameters that is speed, friction pressure, and friction time, forging pressure with three levels low, medium and high. By all the combination of three levels with four parameters we have to conduct the total number of 81 experiments in the full factorial method, but by utilizing the taguchi method and its orthogonal array $\mathrm{L}_{9}$ matrix is selected, that means we can conduct the experiments within 9 runs instead of running 81 runs. After the weld the work pieces are machined so that the flash material is removed the work pieces fig 3, then the standard test specimens are prepared for tensile test. The micro structure of the parent material, heat effected zone and at the weld is observed.

Specimens of work pieces before welding (26 specimens)

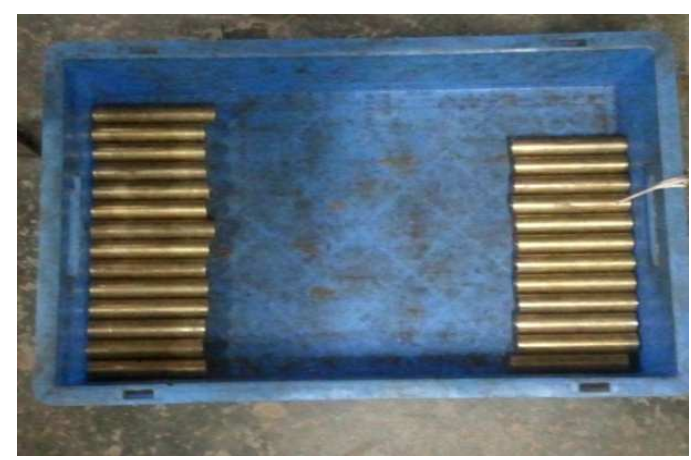




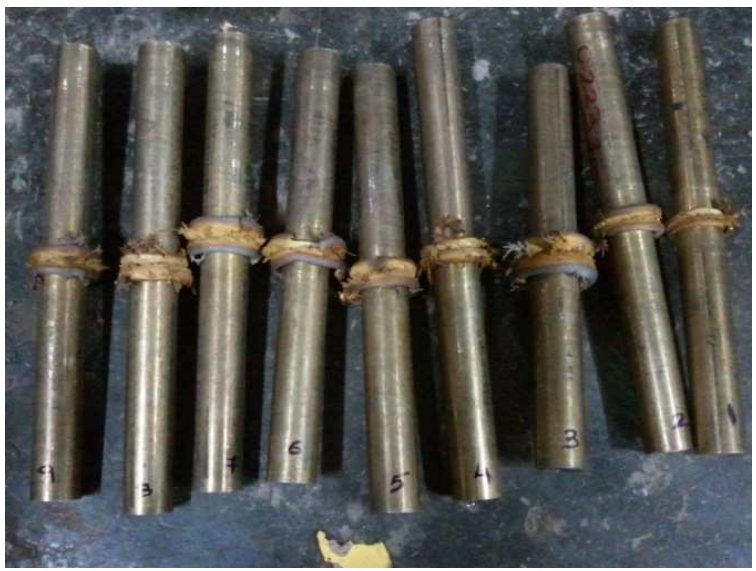

Fig 3: Specimens after Welding

Ultimate Tensile Strength Test results

\begin{tabular}{|c|c|c|c|}
\hline RUNS & $\begin{array}{c}\text { Breaking } \\
\text { Load (N) }\end{array}$ & $\begin{array}{c}\text { Ultimate } \\
\text { Strength } \\
\left(\mathrm{N} / \mathrm{mm}^{2}\right)\end{array}$ & Fractured At \\
\hline 1 & 48200 & 293.9 & WELD \\
\hline 2 & 53000 & 323.17 & WELD \\
\hline 3 & 53600 & 326.69 & NECK \\
\hline 4 & 54600 & 332.92 & NECK \\
\hline 5 & 53400 & 325.09 & WELD \\
\hline 6 & 43400 & 264.63 & WELD \\
\hline 7 & 51400 & 313.4 & WELD \\
\hline 8 & 52000 & 317.07 & WELD \\
\hline 9 & 49800 & 303 & WELD \\
\hline
\end{tabular}

According to the above test results for different Input variables and levels, RUN4 got good tensile strength

\begin{tabular}{|c|c|c|c|c|c|c|c|}
\hline Run & C1 & C2 & C3 & C4 & $\begin{array}{c}\text { Max } \\
\operatorname{Load}(\mathrm{N})\end{array}$ & $\begin{array}{c}\text { Tensile } \\
\text { Strength } \\
\left(\mathrm{N} / \mathrm{mm}^{2}\right)\end{array}$ & $\begin{array}{c}\text { Fracture } \\
\mathrm{d} \text { At }\end{array}$ \\
\hline 4 & $\begin{array}{c}15 \\
00\end{array}$ & 5 & 10 & 30 & 54600 & 332.92 & NECK \\
\hline
\end{tabular}

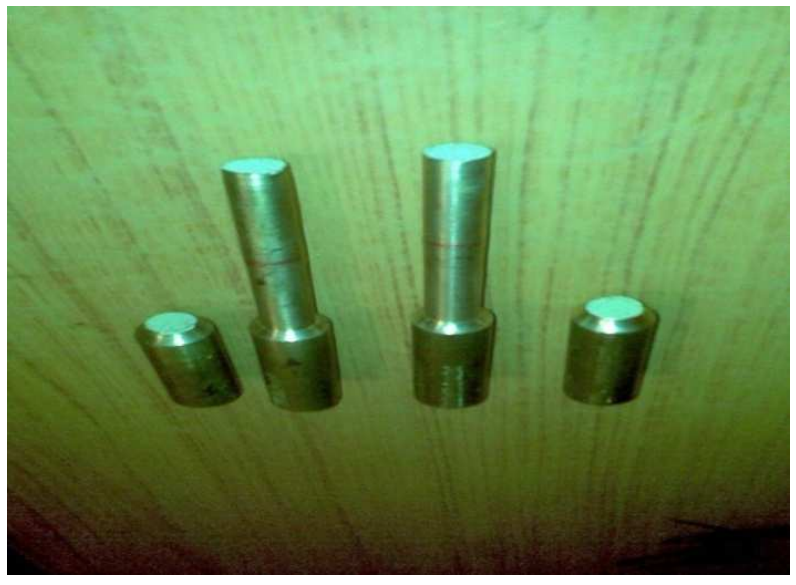

Fig 4: Run 3 and Run 4 braked at the neck portion

Optimum input variables of friction welded joint for Optimum Tensile strength: (Cu Zn28Pb2).

- $\quad$ Rotational speed 1500 R.P.M

- Friction Time $5 \mathrm{Sec}$

- Friction Pressure 10 bar

- Forging Pressure 20 bar

UPSET Test results

\begin{tabular}{|c|c|c|c|c|c|}
\hline Runs & $\begin{array}{c}\mathrm{L} 1 \\
\mathrm{~mm}\end{array}$ & $\begin{array}{c}\mathrm{L} 2 \\
\mathrm{Mm}\end{array}$ & $\begin{array}{c}\mathrm{L}=\mathrm{L} 1+\mathrm{L} 2 \\
\mathrm{~mm}\end{array}$ & $\begin{array}{c}\mathrm{L}_{\mathrm{R}} \\
\mathrm{mm}\end{array}$ & $\begin{array}{c}(\mathrm{L}- \\
\mathrm{L}_{\mathrm{R}} \\
\mathrm{mm}\end{array}$ \\
\hline $\mathbf{1}$ & 96 & 94 & 190 & 185.5 & 4.5 \\
\hline $\mathbf{2}$ & 96.2 & 98 & 194.2 & 183 & 11.2 \\
\hline $\mathbf{3}$ & 95 & 96.2 & 191.2 & 168 & 23.2 \\
\hline $\mathbf{4}$ & 99 & 104 & 203 & 194.7 & 8.3 \\
\hline $\mathbf{5}$ & 96 & 98 & 194 & 183.2 & 10.8 \\
\hline $\mathbf{6}$ & 95 & 95 & 190 & 177.7 & 12.3 \\
\hline $\mathbf{7}$ & 96 & 104 & 200 & 182.9 & 17.1 \\
\hline $\mathbf{8}$ & 95 & 98 & 193 & 184.0 & 9 \\
\hline $\mathbf{9}$ & 98 & 98 & 196 & 182.7 & 13.3 \\
\hline
\end{tabular}

According to the above test results for different Input variables and levels, RUN1 has less axial shortening (UPSET). By studying the test results for tensile and axial shortening, Run 4 parameters shows the highest tensile strength of $332.92 \mathrm{~N} / \mathrm{mm}^{2}$ and for Upset Run 1 parameters shows less loss of length $4.5 \mathrm{~mm}$, but this investigation was mainly concentrated on the tensile strength of the material. 
TABLE: Response Table for Means of Tensile strength

\begin{tabular}{|c|c|c|c|c|}
\hline Level & Speed & $\begin{array}{c}\text { Friction } \\
\text { pressure }\end{array}$ & $\begin{array}{c}\text { Forging } \\
\text { pressure }\end{array}$ & $\begin{array}{c}\text { Friction } \\
\text { time }\end{array}$ \\
\hline 1 & 314.56 & 313.41 & 307.33 & 391.87 \\
\hline 2 & 307.55 & 321.78 & 300.4 & 319.7 \\
\hline 3 & 311.16 & 298.11 & 325.56 & 321.72 \\
\hline Delta & 7.01 & 23.67 & 25.16 & 29.85 \\
\hline Rank & 4 & 3 & 2 & 1 \\
\hline
\end{tabular}

From the above study for parameters we can say that which parameter has greatest influence on the tensile strength, by the response table for Means of tensile strength it is decided that friction time has $1^{\text {st }}$ Rank and forging pressure, friction pressure, speed precedes in the next ranking positions.

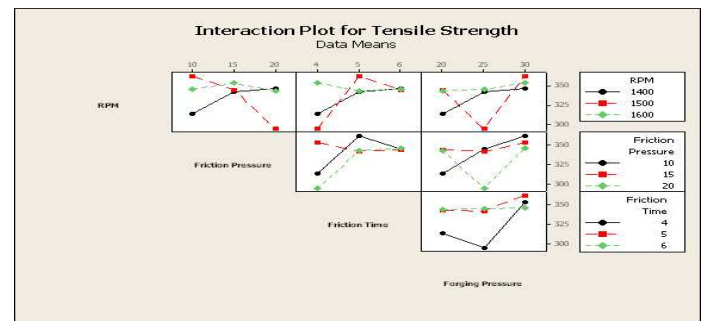

FIG 6: Interaction plot for Tensile strength

Response Table for Means of Upset

\begin{tabular}{|c|c|c|c|c|}
\hline Level & Speed & $\begin{array}{c}\text { Friction } \\
\text { pressure }\end{array}$ & $\begin{array}{c}\text { Forge } \\
\text { pressure }\end{array}$ & $\begin{array}{c}\text { Friction } \\
\text { time }\end{array}$ \\
\hline 1 & 12.96 & 9.96 & 9.53 & 8.6 \\
\hline 2 & 10.46 & 10.33 & 13.53 & 10.93 \\
\hline 3 & 13.13 & 16.26 & 13.5 & 17.03 \\
\hline Delta & 2.67 & 6.31 & 4 & 8.43 \\
\hline Rank & 4 & 2 & 3 & 1 \\
\hline
\end{tabular}

From the above study for parameters we can say that which parameter has greatest influence on the tensile strength, by the response table for Means of tensile strength it is decided that friction time has $1^{\text {st }}$ Rank and friction pressure, forge pressure, speed precedes in the next ranking positions.

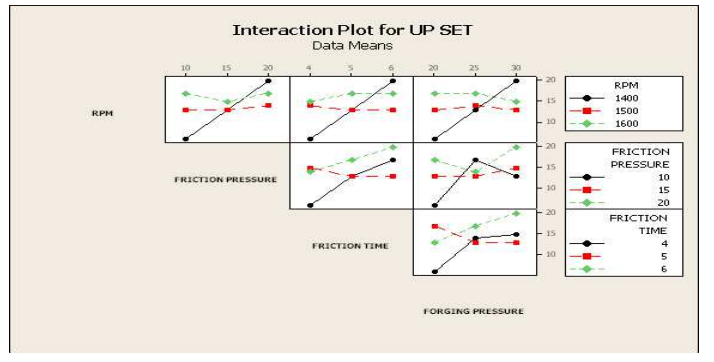

\section{Regression model}

In order to correlate process parameter and tensile strength of welded joints, a nonlinear regression model was developed to predict tensile strength and friction welding of $\mathrm{Cu} \mathrm{Zn} 28$ based on the experimental measured tensile strength. Regression coefficients were calculated using statistical software, MINITAB15.0. after determining significant coefficients at 95\% confidence level, final model developed using only these coefficients to estimate tensile strength .

\section{The regression equation for tensile strength}

TENSILE STRENGTH $=-4542+3.37 \mathrm{C} 1-7.83 \mathrm{C} 3+620$ $\mathrm{C} 2+71.9 \mathrm{C} 4-0.0493 \mathrm{C} 1 * \mathrm{C} 4-0.413 \mathrm{C} 1 * \mathrm{C} 2$

Adequacy of model was tested by using ANOVA. All terms including $\mathrm{C} 1, \mathrm{C} 2, \mathrm{C} 3, \mathrm{C} 4, \mathrm{C} 1 \mathrm{C} 4$, and $\mathrm{C} 1 \mathrm{C} 2$ were significant at $95 \%$ confidence interval. the determination coefficient $\left(\mathrm{R}^{2}\right)$ indicates goodness of fit for model. In this case, $\mathrm{R}^{2}(0.953953)$ 95..3\% indicates good outfit. The value of the adjusted determination coefficient $\mathrm{R}^{2}$ adjusted $=0.949335$ is also high, which indicates a high significance of the model. Predicted $R^{2}$ is also made a good agreement with the adjusted $\mathrm{R}^{2}$ and the $\mathrm{P}$ value for the model is within the limit that is $\mathrm{P}=0.161$.

\section{The regression equation for Upset:-}

UPSET $=-40.79+0.0168 \mathrm{C} 1+0.502 \mathrm{C} 3+2.498 \mathrm{C} 2+0.401$ $\mathrm{C} 4$,

Adequacy of model was tested by using ANOVA. All terms including $\mathrm{C} 1, \mathrm{C} 2, \mathrm{C} 3$, and $\mathrm{C} 4$ were significant at $95 \%$ confidence interval. The determination coefficient $\left(\mathrm{R}^{2}\right)$ indicates goodness of fit for model. in this case, $\mathrm{R}^{2}(0.952855)$ 95.2\% indicates good outfit. The value of the adjusted determination coefficient $R^{2}$ adjusted $=0.903335$ is also high, which indicates a high significance of the model. Predicted $\mathrm{R}^{2}$ is also made a good agreement with the adjusted $\mathrm{R}^{2}$ and the $\mathrm{P}$ value for the model is within the limit that is $\mathrm{P}=0.007$

\section{MICROSTRUCTURE}

The metallographic images of the copper alloy samples are seen before and after the welding is done with the heat effected zone is taken into consideration.

Fig shows the base material microstructure is clearly observed that lead is present in 2-3\% with black patches. 


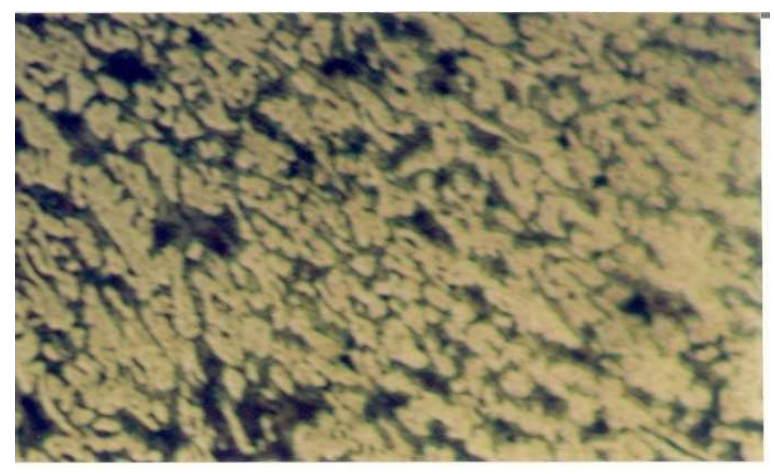

Micro structure of parent material

In the microstructure of base material observed the grains are larger in size. The grain boundaries were visible clearly. And it has small black spots due to the presence of small amount of lead which is around $2-3 \%$.

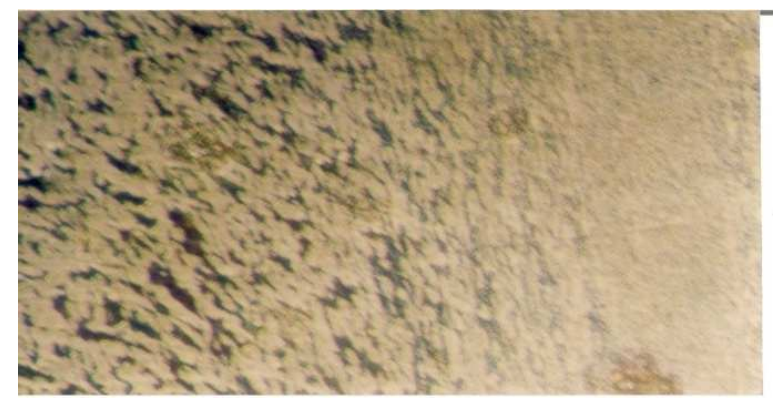

Micro structure of heat affected zone

In the microstructure of the heat affected zone the grain size is decreased compared to grain size of base material. And grain boundaries are not much clear as in base material, because when the grain size decreases, the grains are combined so the grain boundaries are not that clear. And small black spots of lead were decreased to some extent.

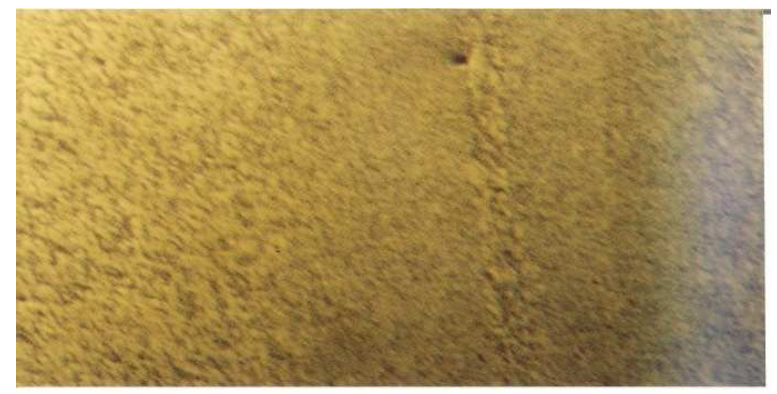

Micro structure of weld zone

At the weld zone observed the grains are very close and smaller in size, indicating that the Joint is excellent.
There are no weld defects, cracks, voids, impurities etc. Grain boundaries were not visible due to fine grains.

Grain size increased when the distance from the weld zone increases that is towards the weld zone, the grain is fine.

In the weld zone structure observed there are no black spots of lead because the lead has low melting temperature than the copper and zinc, hence while welding operation, lead reaches its melting temperature and it is evaporated. Due to this reason there are no black spots in the weld zone.

From the above observations we can say that if the grain size decreases or with the fine grains the strength will increase.

\section{CONCLUSIONS}

Mechanical behavior of the friction welded joint for brass is studied by the Taguchi design of experiment and observed that the friction processed joint exhibited comparable strength with the base material and joint strength increased with increase in forging pressure at high and moderate levels of rotational speeds, and the optimal value of process variables for a higher tensile strength from the Taguchi design is 1500 R.P.M Speed, $5 \mathrm{sec}$ friction time, 10 bar friction pressure and 30 bar forging pressure

It is observed that the Upset is decreased by all factors which are considered in friction welding process. It is found that the optimum values for less upset is 1400R.P.M Speed, $4 \mathrm{sec}$ friction time, 10 bar friction pressure and 20 bar forging pressure.

A study of the regression analysis for both tensile and upset was done and the regression equation for both tensile and upset to predict the values of tensile and upset at any levels of process variables is studied and the correlation between experimental values and predicted values of both tensile and upset was established with a correlation co-efficient of 0.971 and 0.975 respectively which is more than 0.5 and hence Satisfactory as per the Taguchi standards.

Studied the main affect, interaction and contour plots with the help of ANOVA for both tensile and upset and observed that at all levels of variables, There is an interaction between each other. And from the main affect plots it is observed that the level of factors that have more effect on the tensile strength and upset. From the Taguchi design of experiment it is observed that the factor that has more effect on the tensile strength is forging pressure, and on the upset, the effect of all the process variables is uniform.

The microstructure at heat affected zone and weld zone was observed and it is found that the friction welded joint is excellent without any internal defects like blow holes, cracks ,voids, impurities and grade size is fine towards the weld zone. 


\section{REFERENCES}

[1] O. T. MIDLING, O. GRONG and M. CAMPING, in Proceedings of the 12th International Symposium On Metallurgy and Materials Science, Riso, edited by N. Hansen (Riso National Laboratory, Denmark, 1991) PP. 529-534.

[2] .H. KREYE and G. REINER, in Proceedings of the ASM Conference on Trends in Welding Research, Gatlinburg, TN, May 1986 edited by S. David and J. Vitek (ASM International Metals Park, 1986) PP. 728731.

[3] .M.ARITOSHI, K. OKITA, T. ENDO, K. IKEUCHI and F. MATSUDA, Japan. Welding Society. 8 (1977) 50 .

[4] M. J. COLA, M.A.Sc thesis, Ohio State University, OH (1992).

[5] M.J.COLA and W. A. BAESLACK, in Proceedings of the 3rd International. SAMPE Conference, Toronto Oct., 1992, edited by D. H. Froes, W. Wallace, R. A. Cull, and E. Struckholt, Vol. 3, PP 424-438.

[6] .Aeronautics for Europe Office for Official Publications of the European Communities, 2000.

[7] ESSLINGER, J. Proceedings of the 10th World conference of titanium (Ed. G. LUTJERING) WileyVCH, WEINHEIM, Germany, 2003.

[8] .RODER O., Hem D., LUTJERING G. Proceedings of the 10th World conference of titanium (Ed. G. LUTJERING) Wiley-VCH, WEINHEIM, Germany, 2003.

[9] .BARREDA J.L., SANTAMARÍA F., AZPIROZ X., IRISARRI A.M. Y VARONA J.M. "Electron beam welded high thickness Ti6A14V plates using filler metal of similar and different composition to the base plate". Vacuum 62 (2-3), 2001.PP 143-150

[10] EIZAGUIRRE I., BARREDA J.L., AZPIROZ X., SANTAMARIA F. Y IRISARRI A.M. "Fracture toughness of the weldments of thick plates of two titanium alloys". Titanium 99, Proceedings of the 9th World Conference on Titanium: Saint Petersburg, (1999), PP. 1734-1740. 